\title{
Wartenberg Syndrome - an Unusual Neuropathy - Case Report and Literature Review
}

\author{
Mihai MEHEDINTU-IONESCU' , Ovidiu STEFANESCUํ', Radu Cristian JECAN¹,2
}

\begin{abstract}
Almost known in the literature and underdiagnosed even in the obvious cases, Wartenberg syndrome is most often treated, superficially and as a result, with direct consequences on its evolution. These elements ultimately lead to loss of cases and reporting in the literature as a rarity or other condition of the radial nerve, superficial branch.

It must be understood at first that the radial nerve is susceptible to compression in different ways along the anatomical path. Causes are all common in the upper limb, compression and trauma. The two elements (compression and trauma) affect the superficial branch of the radial nerve at the time of its passage between the brachioradial muscle and the supinator muscle, as a result the patients complain of "hand pain". They describe only sensitive disorders but not motor disorders. The pain is described distally by the radial foramen and is accompanied by paresthesia on the dorsal side of the hand. The present case shows a female person working in a car parts factory where they have to pick up considerable parts to inspect them. The pieces are positioned on different side, as a result he must use the muscles of the forearm to turn them.
\end{abstract}

Keywords: Wartenberg syndrome, superficial radial nerve branch.

\section{Rezumat}

Puțin cunoscut în literatură și subdiagnosticat chiar și în cazurile evidente, sindromul Wartenberg este tratat de cele mai multe ori, superficial și drept urmare cu consecințe directe asupra evoluției lui. Aceste elemente duc întrun final la pierderea cazurilor și raportarea în literatura de specialitate ca o raritate sau altă afecțiune a nervului radial, ramura superficială. Trebuie înțeles încă de la început că nervul radial este susceptibil de compresie în diferite moduri de-a lungul traseului anatomic. Cauzele sunt tot cele comune, întâlnite la nivelul membrului superior, compresia și trauma. Cele două elemente (compresia și trauma) afectează ramura superficială a nervului radial în momentul trecerii ei printre muşchiul brahioradial şi muşchiul supinator, drept urmare pacienții se plâng de "dureri de mâini". Descriu doar tulburări senzitive dar nu și motorii. Durerea este descrisă distal de foramenul radial și este însoțită de parestezii pe fața dorsală a mâinii. Cazul de față prezintă o persoană de sex feminin ce lucrează într-o fabrică de subansamble mașini unde trebuie să ridice piese de o greutate considerabilă pentru a le inspecta. Piesele sunt poziționate pe diferite direcții, drept urmare, acesta trebuie să folosească musculatura antebrațului pentru a le întoarce.

Cuvinte cheie: sindrom Wartenberg, ram superficial nerv radial.

\footnotetext{
${ }^{1}$ „Agrippa Ionescu" Emergency Clinical Hospital, Bucharest, Romania

${ }^{2}$ "Carol Davila" University of Medicine and Pharmacy, Bucharest, Romania
}

Corresponding author. Mihai MEHEDINTU-IONESCU, „Agrippa Ionescu” Emergency Clinical Hospital, Bucharest, Romania.

E-mail:drmehedintu@gmail.com 


\section{SUMMARY}

The patient of 45 years, quality controller in a car parts factory, presented in the plastic surgery service for pain in the back of the hand, without being able to define the respective area, without motor deficiency. The patient states that during the rest period, the symptoms disappeared and reappeared about a week after the resumption of activity in the factory. Paraclinical investigations before to the surgery described a lipomantic tumor mass located between the skin and the brachioradial muscle. They could not point to a clear diagnosis. The operative time was defining in establishing a real diagnosis, Wartenberg syndrome. The evolution was favorable but it involved a different life course compared to the time of the surgery.

\section{INTRODUCTION}

About 90 years ago, in a specialized work, Robert Wartenberg describes a series of "painful phenomena» in the forearm at several prisons who had worn along the process that sent him behind bars, handcuffs that had limited the normal movements of the forearm ${ }^{5}$. The evolution of these phenomena could not be properly tracked over time because limited access to convicted persons, prevented their pursuit. As a result, other social categories are pursued, the same phenomena are also encountered in the ladies who wore very tight bracelets or in the gentlemen who embraced a new fashion, of the watches with the strap. The etiology was difficult to specify because it is not clear whether the direct pressure of the constraint element is solely responsible or if the edema associated with constriction also contributes $^{1}$. Cheiralgia, a term used for the first time in describing Wartenberg syndrome, is a neuropathy of the upper limb, underdiagnosed today, caused by compression or weft on the superficial branches of the radial nerve ${ }^{2,3}$. Underdiagnosis occurs when chiralgia is misdiagnosed and confused with Quervaine's syndrome, which describes pain when mobilizing / moving the police ${ }^{4}$. The anatomical area of the affected forearm is the dorsal face and the base of the police, sometimes being described as parestases on the dorsal face of the hand. Symptoms usually resolve within a few months, when the cause is removed; NSAIDs are commonly prescribed $^{4}$. In some cases, surgical decompression is required ${ }^{4}$. The effectiveness of cortisone treatment is challenged, with the possibility of permanent damage but biological material such as the amniotic membrane are investigated with promising results ${ }^{11}$.

\section{CASE REPORT}

A 45-year-old woman, Caucasian, middle school, urban, working for about 3 years in a factory of car parts, insignificant family history, personal history: intraocular hypertension. Presented in the emergency room where after examining the right forearm, a like-tumoral formation is observed in the upper third, which has a not very hard consistency, cannot be mobilized on the deep planes, the teguments do not have a significant change in the normal, slightly pink coloration. At the supination of the forearm or the flexion of the fingers, the color changes to the tegument, at about 30 seconds of effort are evident and the forearm becomes hard in the upper third and with an increase in circumferential volume. Anamnestic, the patient declares: for about 6 months, during the working period, there is a pain about 2-3 hours from the beginning of the program in the
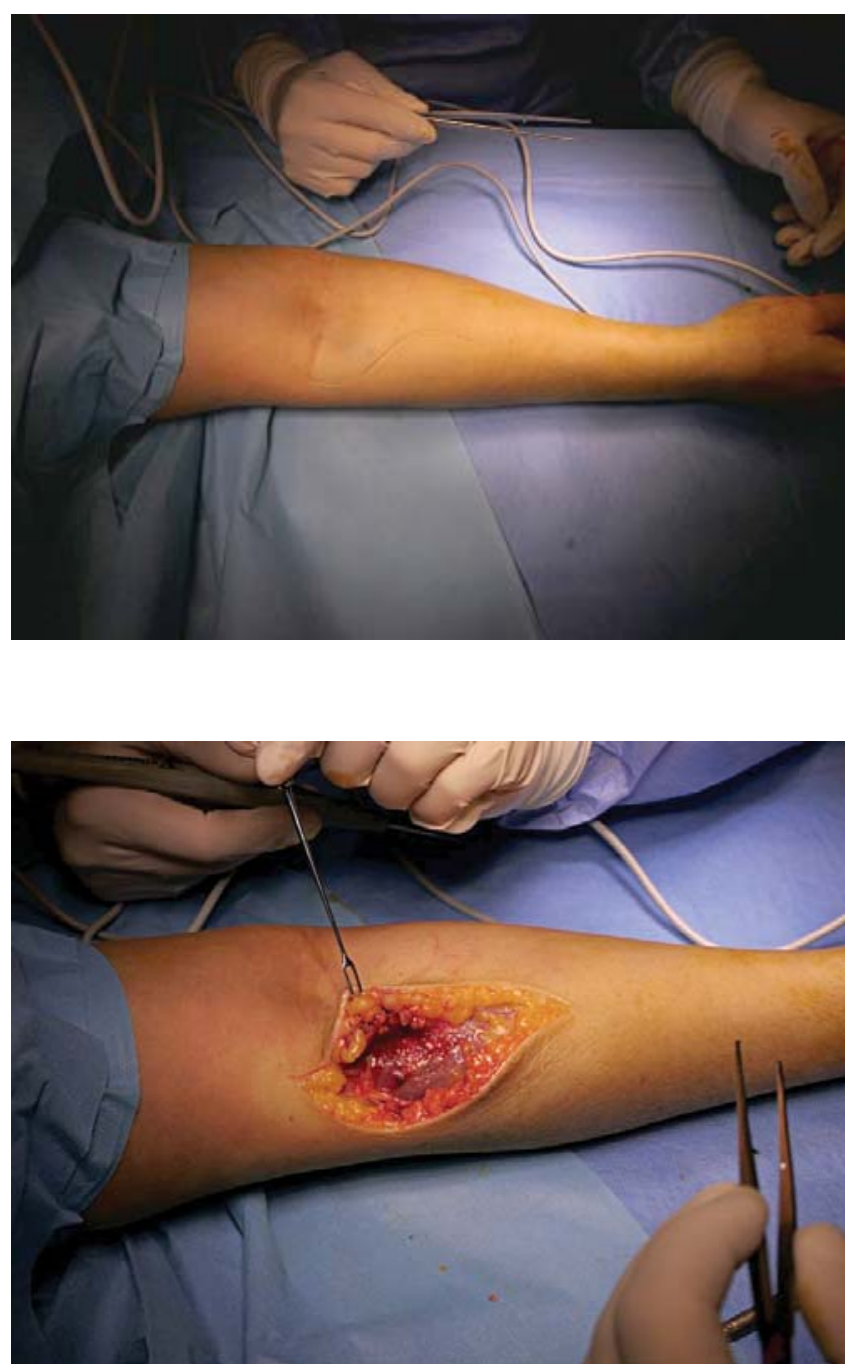

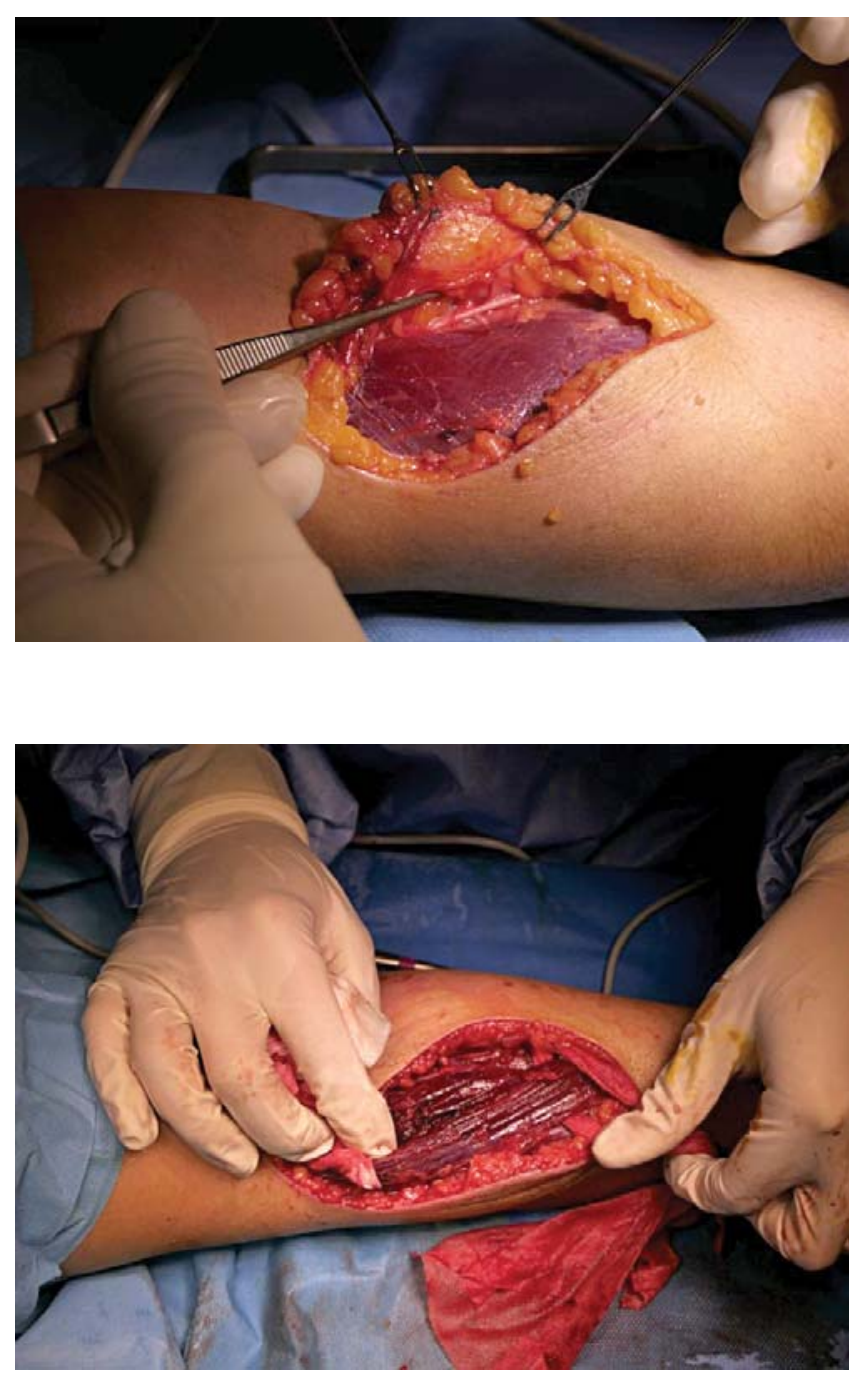

factory. The pain persists and is followed in about an hour by the appearance of a colour of the tegument of different tendency to the rest of the forearm that becomes pale. The pain is accompanied by mild paraesthesia in the carpal tunnel and the eminence of the straight tendon. After completing the program, the forearm regains its normal colour and the pain disappears overnight. These neurological phenomena are not so obvious during the weekend, especially if there is no homework. The patient presents to the hospital one month after the end of the leave. This is the main reason, because during the 14-day rest days, the neurological phenomena and the increased volume of the forearm disappeared. With the resumption of work, phenomena described above have reappeared. The patient is asked to describe exactly what he is doing in the factory. $\mathrm{He}$ states that he must take pieces of considerable weight, about 10 kilos, stored in boxes on the floor and put on

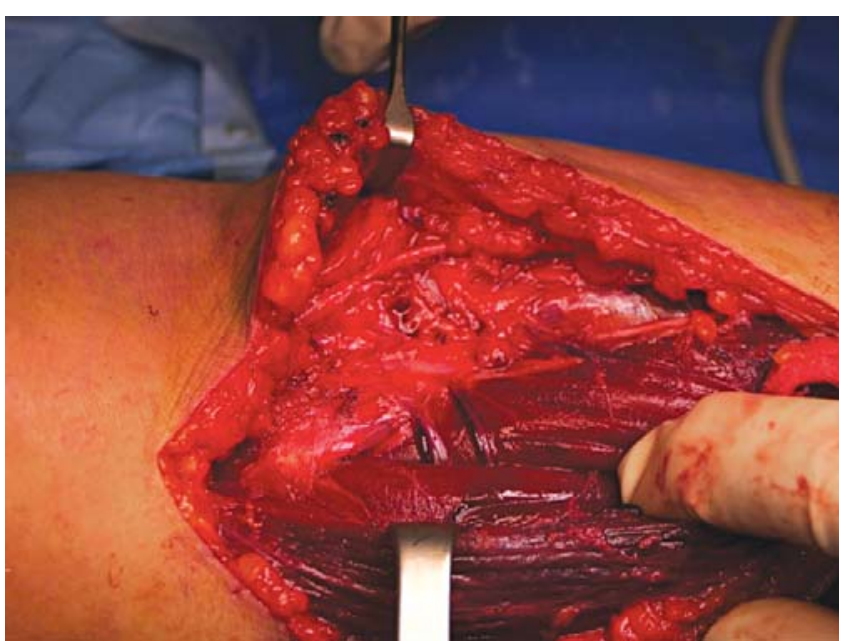

an inspection table, then returned to different positions, eventually put back in the same boxes. The patient is a quality controller. An anamnestic element that did not seem important in the first phase was that in youth, the patient performed sports of performance, athletics. For the patient, the dominated hand is right. Also anamnestic the patient states that she performed an electromyogram that was in normal parameters throughout the brachial plexus. The ultrasound performed in the home town specifies the presence of a stronger vascularization at the level where the like-tumour is observed. It is also decided to perform a computer-tomographic examination. The result is not conclusive for the diagnosis: adipose tissue present and the intermuscular planes and a more pronounced vascularization that seemed to serve the adipose tissue. The operative time made the clear diagnosis of Wartenberg's syndrome by an anatomical variant of the brachioradial muscle that presented two muscular bodies, each with its own arterial source. As a result the muscle mass was twice as large, the vascularization described ultrasound as well as the CT examination belonged to the muscle mass. The fatty tissue was unchanged. The mobilization of the muscle mass during the work finally led to the development of a compartment quasi-syndrome that compresses the branch of the radial nerve.

\section{DISCUSSIONS}

The literature confirms once again the underdiagnosis of Wartenberg syndrome. The causes and the subsequent evolution, after the elimination of the supposed cause, are uncertain nowadays. They were not cited in $20^{\text {th }}$ century specialty literature. After further deve- 
lopment of the paraclinical investigations, the pathology has diversified ${ }^{13-15}$. The local internal causes can be considered as irritating elements on the nerves that also have sensitive components ${ }^{6}$. The changes in architecture are, in the first phase, sensitive, disturbances of sensitivity in the area corresponding to the area served, is poorly differentiated and difficult to sustain also by the clinician who must orient it in a clinical picture. The elimination of external causes and the lack of internal causes will shortly improve the quality of life of the patients ${ }^{6,7}$. Wartenberg's syndrome is a small part of the radial nerve pathology but which requires the experience and attention of the doctor in order not to misdiagnose and consequently subject the patient to inadequate treatment ${ }^{8}$. Exposure to paraclinical diagnostic elements, electromyogram and imaging is mandatory. Without these elements, the diagnosis is anamnestic and may be confused ${ }^{9}$. Many articles that can be consulted in the specialized literature describe causes that may be close to the sensitive branch, but few of them clearly fall into the Wartenberg syndrome.

\section{References}

1. Pećina, Marko; Krmpotić-Nemanić, Jelena; Markiewitz, Andrew D. (2001). "Chapter 26: Syndrome of the Superficial Branch of the Radial Nerve". Tunnel syndromes: peripheral nerve compression syndromes. CRC Press. pp. 152-155.

2. Braidwood, A. S. (1975). "Superficial Radial Neuropathy”. Journal of Bone and Joint Surgery. 57-B (3): 380-383. doi:10.1302/ 0301-620X.57B3.380. Archived from the original on 2011-07-24.

3. Buttaravoli, Philip M.; Stair, Thomas 0. "9.20 Cheiralgia Paresthetica (Handcuff Neuropathy)". Common Simple Emergencies. Washington: Longwood Information.

4. Dang, Alan C.; Rodner, Craig M. (December 2009). "Unusual Compression Neuropathies of the Forearm, Part I: Radial Nerve" (PDF). Journal of Hand Surgery. 34A (10): 1912-1914. doi: 10.1016/j.jhsa.2009.10.016. PMID 19969199.

5. Decreased expression of IncRNA Malat1 in rat spinal cord contributes to neuropathic pain by increasing neuron excitability after brachial plexus avulsion. Meng $\mathrm{C1}, 2,3$, Yang $X 1,2,3$, Liu Y1,2,3, Zhou Y1,2,3, Rui J1,2,3, Li S1,2,3, Xu C1,2,3, Zhuang Y4, Lao J1,2,3, Zhao X1,2,3. 1 Department of Hand Surgery, Huashan Hospital, Fudan University, Shanghai 200040, People's Republic of China. 2 Key Laboratory of Hand Reconstruction, Ministry of Health, Shanghai 200032, People's Republic of China. 3 Shanghai Key Laboratory of Peripheral Nerve and Microsurgery, Shanghai 200032, People's Republic of China. 4 Hand Surgery Department, Shenzhen People's Hospital, Shenzhen 518020, People's Republic of China./// J Pain Res. 2019 Apr 23;12:1297-1310. doi: 10.2147/JPR.S195117. eCollection 2019.

6. Prospective evaluation of sleep improvement after cubital tunnel decompression surgery. Said J1, Abboudi J2, Gallant G2, Jones C2, Kirkpatrick W2, Liss F2, Rivlin M2, Takei RR2, Wang M2, Silverman M2, Foltz C2, Ilyas AM2. :1 Rothman Institute, Thomas Jefferson University, Philadelphia, PA, USA. Electronic address: joseph.saidmd@gmail.com. 2 Rothman Institute,

\section{CONCLUSIONS}

- Subdiagnosis of Wartenberg syndrome is common

- The treatment is inappropriate for the pathology

- Frequent confusion occurs with the de Quervain tendinitis

- The causes of the syndrome are little known and sometimes, even obvious, they are not considered for diagnosis

Compliance with ethics requirements: The authors declare no conflict of interest regarding this article. The authors declare that all the procedures and experiments of this study respect the ethical standards in the Helsinki Declaration of 1975 , as revised in 2008(5), as well as the national law. Informed consent was obtained from all the patients included in the study.

Thomas Jefferson University, Philadelphia, PA, USA. J Shoulder Elbow Surg. 2019 May;28(5):e144-e149. doi: 10.1016/j. jse.2018.11.046. Epub 2019 Jan 23

7. Hand compression neuropathy: An assessment guide. MacGillis KJ1, Mejia A2, Siemionow MZ2. Author information: 1 Department of Orthopaedic Surgery, University of Illinois at Chicago, IL, USA. Email: kylemacgillis@gmail.com. 2 Department of Orthopaedic Surgery, University of Illinois at Chicago, IL, USA // J Fam Pract. 2016 Jul;65(7):462-71.

8. Radial tunnel syndrome. Naam NH1, Nemani S. Plastic and Reconstructive Surgery, Southern Illinois Hand Center, Southern Illinois University, Effingham, IL 62401, USA. drnaam@handdocs.com. Orthop Clin North Am. 2012 Oct;43(4):529-36. doi: 10.1016/j.ocl.2012.07.022.

9. Ulnar Tunnel Syndrome, Radial Tunnel Syndrome, Anterior Interosseous Nerve Syndrome, and Pronator Syndrome. Strohl AB1, Zelouf DS. From the Philadelphia Hand Center (Dr. Strohl), and the Thomas Jefferson University Hospital, Philadelphia, PA (Dr. Zelouf). J Am Acad Orthop Surg. 2017 Jan;25(1):e1-e10. doi: 10.5435/JAAOS-D-16-00010.

10. An unexpected side effect: Wartenberg syndrome related to the use of splint during carpal tunnel syndrome treatment. Serçe A1, Karaca Umay E1, Karaahmet ÖZ1, Çakcı FA1. Department of Physical Medicine and Rehabilitation, Dışkapı Yıldııı Beyazıt Training and Research Hospital, Ankara, Turkey.

11. Neurolysis with Amniotic Membrane Nerve Wrapping for Treatment of Secondary Wartenberg Syndrome: A Preliminary Report. Gaspar MP1, Kane PM1, Vosbikian MM2,3, Ketonis C2, Rekant MS1. J Hand Surg Asian Pac Vol. 2017 Jun;22(2):222-228. doi: 10.1142/S0218810417200015.

12. Multiple schwannomas of the digital nerves and superficial radial nerve: two unusual cases of segmental schwannomatosis. Gosk J1, Gutkowska O, Kuliński S, Urban M, Hałoń A. Jerzy 
Gosk, Department of Traumatology, Clinic of Traumatology and Hand Surgery, Wroclaw Medical University, 213 Borowska St., 50-556 Wrocław, Poland, phone: +48 7173438 00, fax: +48 71 73438 09, e-mail: chiruraz@umed.wroc.pl. Folia Neuropathol. 2015;53(2):158-67.

13. Nervous Regeneration Allograph Type of Periferic Nerv. Mihai MEHEDINTU-IONESCU1, Ovidiu STEFANESCU1, Radu Cristian JECAN2 //„Agrippa Ionescu" Emergency Clinical Hospital, Bucharest, Romania //2 "Carol Davila" University of Medicine and Pharmacy, Bucharest, Romania. Modern Medicine | 2019, Vol. 26, No. 2

14. Unusual median nerve schwannoma: a case presentation ANDREA ANGHEL1,2), IRINA TUDOSE3), DANA TERZEA2,4), LAURA RĂDUCU5), RUXANDRA DIANA SINESCU1,2) // 1)Department of Plastic Surgery and Reconstructive Microsurgery, "Elias" Emergency University Hospital, Bucharest, Romania / 2) "Carol Davila" University of Medicine and Pharmacy, Bucharest, Romania / 3)Department of Pathology, "Elias" Emergency University Hospital, Bucharest, Romania / 4) Oncoteam Diagnostic, Bucharest, Romania / 5)Department of Plastic Surgery, "Prof. dr. Agrippa Ionescu" Military Emergency Hospital, Bucharest, Romania // Rom J Morphol Embryol 2014, 55(1):159-164
15. Open Carpal Tunnel Release: Performed Axillary Brachial Plexus Block Versus Wide Awake LAURA RADUCU1,2, ADELAIDA AVIN01* CRISTINA-NICOLETA COZMA1,2, ANDRA-ELENA BALCANGIU-STROESCU3,4, DELIA TIMOFTE3,5, MARIA DANIELA TANASESCU6,7, DANIELA GABRIELA BALAN4, CRISTIAN-RADU JECAN1,2, DORIN IONESCU6,7// 1 Prof. Dr. Agrippa Ionescu Clinical Emergency Hospital, Department of Plastic and Reconstructive Surgery, 7 Ion Mincu, 011356, Bucharest, Romania, 2 Carol Davila University of Medicine and Pharmacy, Faculty of Medicine, Discipline of Plastic and Reconstructive Surgery, 37 Dionisie Lupu Str., 020021, Bucharest, Romania, 3 Emergency University Hospital Bucharest, Department of Dialysis, 169 Splaiul Independenei, 050098, Bucharest, Romania, 4 Carol Davila University of Medicine and Pharmacy, Faculty of Dental Medicine, Discipline of Physiology, 37 Dionisie Lupu Str.020021, Bucharest, Romania, 5 Dialysis Center Sema Parc, Bucharest, 319 Splaiul Independenei 060044, Bucharest, Romania, 6 Emergency University Hospital Bucharest, Department of Nephrology, 169 Splaiul Independenei, 050098, Bucharest, Romania, 7 Carol Davila University of Medicine and Pharmacy, Faculty of Medicine, Department of Medical Semiology, Discipline of Internal Medicine I and Nephrology, 37 Dionisie Lupu Str., 020021 , Bucharest, Romania -//- http://www.revistadechimie.ro REV. CHIM.(Bucharest), 70, No. 5, 2019 
